\title{
IMPLEMENTASI PENGAKUAN DAN JAMINAN HAM SEBAGAI UPAYA PENGUATAN INTEGRASI BANGSA
}

\author{
Oleh : \\ Nadir
}

\begin{abstract}
The existence of radicalism movement recently has made us worried about the nation and state life in the world order, since this movement is able to attract others from various elements of people and states that the teachings and ideology the movement offers are good. This movement at last will influence either the national or international stability because it is wellorganized. Therefore, it is necessary to reinforce the recognition and assurance of human rights especially the prosperity of the state that may make Indonesian people easy to be attracted by any offerings given by the groups of this radical movement. If in the past the movement of human rights was constructed by the thinkers due to arbitrarv rulers, at present human rights is moved and thought in order to strengthen the national integration. The alarming development of transnational radicalism movements has given impacts on a national disintegration, therefore, the principle of recogmtion and assurance in the protection of human rights is lead to protect, save, and to assure the prosperity porn the state since few peoplejoining in a radical movement are not caused ofjihad but of economic reasons. If the state seriously give some recognition and assurance of human rights, the citizens feel to be protected. This in turns results in a sympathetic emphatic feelings to the government and the state, and therefore the national integration will still be kept intact and well-woven.
\end{abstract}

Kata Kunci: integrasi bangsa, HAM, Negara hukum

\section{PENDAHULUAN}

Munculnya gerakan radikalisme transnasional di beberapa Negara di dunia merupakan bentuk kekecewaan terhadap pemerintahan suatu negara karena dianggap kurang memberikan jaminan dan pengakuan terhadap hak-hak mereka. Kondisi itulah yang menyebabkan mereka membalik arah untuk membentuk gerakan-gerakan radikal guna mencari dan

• Dosen Fakultas Hukum Universitas Madura (UNIRA) Pamekasan membangun legitimasinyasekalipunmelanggarhukum Negara (state law) dan melawan pemerintahan.

Kondisi tersebut mencemaskan kehidupan berbangsa dan bernegara khususnya di Indonesia, kerana tidak sedikit warga Negara Indonesia ditengarahi berangkat ke luar negeri dan bergabung dengan gerakan-gerakan radikalisme dengan berbagai macam alasan yang justru sebenarnya masalah kondisi hak ekonomi yang tak kunjung sejahtera. Jika Negara sudah mampu memberikan dan menjamin hak-hak 
mereka, maka kecil kemungkinan niscaya mereka bergabung dengan gerakan-gerakan radikalisme yang justru melanggar norma-norma hukum Negara.

Persoalan tentang manusia sejak dulu memang menarik perhatian sebagai suatu kelompok problematik tersendiri. Menurut Martin Buber sebagaimana yang dikutip oleh B. Simanjuntak mengemukakan bahwa manusia menjadi masalah karena faktorfaktor sosio kultural.Perubahan pergaulan hidup yang meniadakan rasa aman, dunia teknik yang menguasai manusia, dunia ekonomi yang tidak menunjukkan keseimbangan produksi dan konsumsi, menggelisahkan manusia. $^{2}$

Dengan demikian, kegelisahan itu membuat manusia cenderung nekad berbuat semaunya sendiri tanpa melihat efek-efek samping yang akan merugikan orang lain. Dalam keadaan demikian, timbullah apa yang disebut dengan teori kekuasaan orang siapa yang kuat pasti menang dan langgeng dengan segala cara dilakukan tanpa melihat dampak negatifnya. Itulah Machiavelli berpesan segala cara dihalalkan untuk dilakukan dalam merebut dan mempertahankan kekuasaan.

Perbuatan yang akan menimbulkan kesengsaraan, kegelisahan dan keresahan bagi orang lain jelas telah melanggar Hak Asasi Manusia (HAM), sampai kapan perubahan keseimbangan kehidupan antara sesama manusia di muka bumi ini akan terwujud, mungkin keseimbangan itu akan ada, kekacauan itu musnah, kekerasan itu hilang, kedengkian itu hancur setelah semua mengalami kemusnahan akan segala kehidupun di dunia ini yang dilenyapkan oleh sang peciptanya.

Bahkan mungkin kekerasan antar sesama manusia itu merupakan sejarah awal peradaban manusia yang terjadi pada masa lampau, masa kini, dan masa yang akan datang selama manusia itu hidup beriringan antar sesama manusia di dunuia.

Jika dicermati kebelakang masalah Hak Asasi Manusia (HAM) adalah mosaik sejarah tentang penegakan kemerdekaan, kebebasan, keadilan, persamaan, perdamaian, persaudaraan dan perlindungan. Mosaik yang mengalami pasang surut dalam cerminan kecemerlangan dan keburamaan jutaan wajah umat manusisa, hampir menjadi kenyataan bahwa

${ }^{2}$ Abdul Wahid dan Muhammad Irfan, Perlindungan Terhadap Korban Kekerasan Seksual: Advokasi Atas Hak Asasi Perempuan, (Bandung: Refika Aditama, 2001), hlm.1 penindasan (pelanggaran) terhadap Hak Asasi Manusia (HAM) menempati fragmentasi histories dengan fenomena yang berulangkali, bahwa rekaman sejarah terhadap nasib HakAsasi Manusia (HAM) juga senantiasa menyuarakan bagian-bagian pembelanya yang heroic atas musnahnya kemerdekaan itu sendiri. Bahkan dengan nada sedikit kecewa, problema Hak Asasi Manusia (HAM) telah berkembang sedemikian krusial, sehingga menjadi dilema global. ${ }^{3}$

Meskipun demikian, problem yang berkaitan dengan Hak Asasi Manusia (HAM) tersebut adalah setua usia sejarah kehidupan manusia. Sejak zamannya Nabi Adam yang disebut sebagai awalnya kehidupan manusia, persoalan Hak Asasi Manusia(HAM) sudah terjadi. Misalnya saat putranya bernama Qabil berlaku jahat dengan membunuh adiknya yang bernama Habil, maka pada saat itu telah terjadi pelanggaran Hak Asasi Manusia (HAM), yakni berbentuk perlakuan kejam dan tidak manusiawi terhadap sesamanya. Kasus seperti itu telah mendeskripsikan secara historis, bahwa pelanggaran HakAsaşi Manusia (HAM) sudah terjadi setua usia kehidupan manusia itu sendiri. Dengan pendekatan histories ini, cukup logis jika diskursus (perbincangan) mengenai Hak Asasi Manusia (HAM) seperti tidak mengenal kata akhir. Pakar-pakar ilmu politik, agama, hukum, budaya, ekonomi dan filsafat terus berusaha mengkaji serta menganalisis tentang berbagai persoalan HakAsasi Manusia(HAM) dengan disiplin ilmunya. ${ }^{4}$

Namun demikian, cepat atau lambat perubahan pasti senantiasa ada menyertai kehidupan manusia karena bumi masih berputar dan kehidupan serta penghidupan masih berjalan normal sehingga mampu menghadirkan suasana yang proporsional dan harmonis serta akuntabel sesuai dengan materi muatan yang ditawarkan seperti perkembangan ilmu pengetahuan, teknologi informasi, iman dan taqwa yang mampu mempengaruhi polapikir, gaya hidup, model interaksi sosial, kultural, ekonomi, hukum, dan politikyang sedang berjalan akhirnya timbullah pemahaman hak-hak seseorang yang memang seyogiayanya harus dihormati dan dijunjung tinggi.

${ }^{3}$ M. Luqman Hakiem, Dekalarasi Islam Tentang HAM, (Surabaya: Risalah, 1993), hlm.

${ }^{4}$ Muhammad Tholchah Hasan, Kekerasan Terhadap Perempuan Sebagai Pelanggaran HAM, dalam Abdul Wahid dan Muhammad Irfan, ............ Op.Cit, hlm.vii 
Potensi utama dalam merubah ketidakstabilan dan ketidakseimbangan tersebut semua ditentukan oleh keinginan dan kemauan manusia itu sendiri sebagai subjek hukum dan penyelenggara Negara yang sekaligus menjadi penentu atas terjadi dan membaiknya sikap tindak manusia dalam kehidupan antar sesama manusia yang akan penulis jelaskan berikut.

II. NEGARA HUKUM SEBAGAI ORGANISASI UTAMA PEMANGKU DAN PENGEMBAN HAK ASASI MANUSIA (HAM) DALAM MEMBANGUN INTEGRASI BANGSA

Negara hukum menjadi pilar utama pemangku dan pengemban untuk merumuskan konsepsi guna mewujudkan jaminan dan perlindungan Hak Asasi Manusia (HAM) yang pada dasarnya sejak awal berdiri negara hukum sudah mencanangkan diri untuk memberikan perlindungan terhadap HakAsasi Manusia (HAM) kepada setiap warganya yang dirumuskan dalam konstitusinya.

Mengenai HakAasi Manusia (HAM) yang berkaitan dengan hak-hak warga Negara, Al Maududi mengemukakan bahwa dalam Islam hak asasi pertama dan utama warga negara adalah melindungi nyawa, harta dan martabat mereka bersama-sama dengan jaminan bahwa hak ini tidak kami dicampuri, kecuali dengan alasan-alasan yang sah dan legal. Perlindungan atas kebebasan pribadi. Kebebasan pribadi tidak bisa dilanggar kecuali setelah melalui proses pembuktian yang meyakinkan secara hukum dan memberikan kesempatan kepada tertuduh untuk mengajukan pembelaan. ${ }^{5}$

Jaminan perlindungan Hak Asasi Manusia (HAM) tidak akan didapat oleh setiap warga negara jika tidak ada sebuah instrumen hukum yang mengaturnya, walaupun pada dasarnya Hak Asasi Manusia (HAM) itu sudah ada dan melekat (inherent) pada setiap warga negara sejak ia lahir, tetapi ketika Hak Asasi Manusia (HAM) itu dilanggar oleh orang lain hendak ke mana Hak Asasi Manusia (HAM) itu dituntut, jika bukan kepada negara sebagai organisasi tertinggi yang memberikan jaminan perlindungan Hak Asasi Manusia (HAM) kepada setiap warganya.

${ }^{5}$ Mawlana Abu A'la Mawdudi, Hak-Hak Asasi Manusia Dalam Islam. Terjemahan dari Human Right in Islam oleh Bambang Iriana Djajaatmadja, (Jakarta, 2000), hlm. 22-23.
Namun di sisi lain, negara berkewajiban memberikan jaminan dan perlindungan HAM kepada setiap warganya, karena negara didirikan untuk memberikan rasa aman, rasa tentram, rasa damai, rasa sejahtera lahir dan batin dalam tertib kehidupan berbangsa dan bernegara. Munculnya gerakangerakan radikalisme disebabkan kerana pengakuan dan jaminan Hak-Hak mereka kurang diperhatikan hanya diakui dan dijamin sebatas aturan normatif tidak dimbangi secara implementatif. Seandainya negara mampu memberikan hal itu semua maka niscaya penguatan integrasi bangsa akan terjamin dan terjalin.

Hal tersebut merupakan tanggung jawab negara yang harus diwujudkan dalam waktu relatif cepat, di mana sudah didambakan sejak Plato Menulis Nomoi, E. Kant memaparkan prinsip-prinsip Negara hukum (formil), J. Stahi mengetangahkan Negara hukum (material).AV. Dicey mengajukan rule oflaw. ${ }^{6}$

Menurut A.V. Dicey dari kalangan anglo sexon memberikan ciri-ciri negara hukum (the rul oflaw) sebagai berikut:

1. Supremacy of Law (supremasi hukum, dalam artian tidak boleh ada kesewenang-wenangan dengan konsekuensi seseorang hanya boleh dihukum jika melanggar hukum).

2. Equality before the law (kedudukan yang sama di depan hukum baik bagi rakyat biasa maupun bagi pejabat).

3. Terjaminnyahak-hak asasi manusia oleh undang undang dan keputusan-keputusan Pengadilan.?

Dalam kaitan ini, negara hukum menjamin adanya tertib hukum dalam masyarakat, artinya memberi perlindungan hukum pada masyarakat: antara hukum dan kekuasaan ada hubungan timbal balik. Negara RepublikIndonesiadibentuk sebagai negara hukum ${ }^{8}$. Artinya negara akan tunduk pada hukum, peraturanperaturan hukum berlaku pula bagi segala badan dan alat perlengkapan negara sekalipun mereka yang membuat hukum, hukum berlaku pula baginya tanpa kekecualian.

\footnotetext{
${ }^{6}$ Oemar Seno Aji, Indonesia Negara Hukum Dalam Seminar Ketatanegaraan UUD 1945 Dalam Padmo Wahjono, Indonesia Negara Berdasarkan Atas Hukum, hlm. 7

${ }^{7}$ Moh. Mahfud, MD, Demokrasi dan Konstitusi di Indonesia, (Yogyakarta, 1993), hlm. 27

${ }^{8}$ vide Pasal 1 ayat (3) amandemen ke-3 UUD 1945
} 
Robert Von Mohl seorang pemikir yang tidak kalah cemerlangnya dengan pemikir terdahulu seperti F.J. Stahl, Immanuel Kant, dari kalangan tradisi hukum Eropa Kontinental, mengemukakan tentang cita-cita negara hukum yang di dalamnya tercermin adanya jaminan hak atas warganya:

1. Negara hukum adalah negara yang diperintah oleh hukum.

2. Akan tetapi tidak cukup hanya memperhatikan aspek formalnya saja dari negara hukum.

3. Negara hukum harus dibentuk dengan memperhatikan aspek materienlya.

4. Hukum harus membatasi kekuasaan negara yang absolut.

5. Adanya jaminan hukum akan hak-hak warga negara.

Adanyajaminan perlindunganHakAsasi Manusia (HAM) bagi setiap warga negaranya ditiap-tiap negara dunia ini mengindikasikan bahwajaminan HAM bagi warganya menjadikan jalinan kasih sayang negara terhadap warganya agar terlepas dari bergabung dengan gerakan-gerakan radikalisme yang menjanjikan sejuta harapan hampa bagi mereka, dan jaminan HAM merupakan asas yang sangat khas dalam sebuah negara hukum baik negara-negara yang menganut civil law system maupun common law system dan negara hukum Pancasila perspektifIndonesia. Rumusan perlindungan terhadap HakAsasi Manusia (HAM) merupakan perlawanan dari tindakan penguasa negara yang sewenang-wenang terhadap warganya.

\section{III.REFLEKSI HAK ASASI MANUSIA (HAM) SEBAGAI PENGUAT INTE- GRASI BANGSA}

Setelah dunia mengalami 2 (dua) perang yang melibatkan hampir seluruh dunia di manaHakAsasi Manusia (HAM) di injak-injak, timbul keinginan untuk merumuskan hak asasi manusia itu dalam suatu naskah internasional. Usaha ini pada tahun 1948 berhasil dengan diterimanya Universal declaration of human Rights (pernyataan sedunia tentang Hak asasi manusia) oleh negara-negara yang tergabung di dalam Perserikatan Bangsa-Bangsa. ${ }^{9}$

${ }^{9}$ Miriam Budiardjo, Dasar-Dasar Ilmu Politik, (Jakarta: Gramedia, 1988), hlm. 120 .
Refleksi Hak Asasi Manusia (HAM) sebagai penguat integrasi bangsa tak dapat disangkal. Hal itu dapat dibuktikan dengan adanya negara-negara yang memang serius memberikan pengakuan dan jaminan secara normatif dan empirik terhadap warganya tat kala pengakuan dan jaminan HAM itu diberikan, warga terasa dilindungi, terasa diayomi yang pada gilirannya akan timbul rasa simpati dan empati terhadap pemerintah dan negaranya, sehingga integrasi bangsa akan tetap utuh dan terjalin.

Memang diakui setiap manusia akan tertuju pada sifat kemanusiaan yang melekat pada manusia itu sendiri, walaupun memiliki perbedaan pandangan antara negara yang satu dengan negara yang lainnya akan Hak Asasi Manusia, tapi Hak Asasi Manusia adalah hak yang bersifat universal dalam pengertian bentuk Hak Asasi Manusia yang diakui oleh tiap negaradi dunia, bahwa setiap manusiamemiliki bentuk hak yang harus dilindungi. Kondisi jaminan HAM ini akan mampu mengintegrasikan bangsa melalui jalinan pengakuan dan perlindungan HAM baik secara normatifdan empirik.

Munculnya gerakan radikalisme akhir-akhir ini mampu mencemaskan kondisi kehidupan berbangsa dan bernegara dalam tertib kehidupan dunia, karena gerakan itu mampu menarik simpati orang lain dari berbagai kalangan dan berbagai warga negara di dunia yang menyakini akan paham dan ajaran yang ia tawarkan, gerakan ini cepat atau lambat akan mempengaruhi stabilitas nasional maupun internasional karena sifatnya terorgansir, sehingga dalam kajian penulis, perlu adanya penguatan pengakuan dan jeminan HAM khususnya kesejahteraan dari negara agar warga negara Indonesia tidak mudah tergiur tawaran yang ditawarkan oleh kelompok gerakan radikalisme ini.

Shalahuddin Hamid, memberikan ilustrasi pemakaian HakAsasi Manusia(HAM) dalam menyebut human right tidak tepat, sebab arti hak manusia sudah mencakup arti Hak Asasi Manusia, namun ia menyampingkan perdebatan istilah tersebut karena keumuman di masyarakat adalah menggunakan istilah HakAsasi Manusia (HAM) (human right). ${ }^{10}$

Secara terminologis Hak Asasi Manusia adalah kebenaran yang diperjuangkan kewenangannya dan

${ }^{10}$ Shalahuddin Hamid, Hak Asasi Manusia Dalam Perspektif Islam, cet. Ke-2, (Jakarta: Amissco, 2003), hlm. 10 
menjadi milik individu, kelompok sesuai dengan cara pandang terhadap kebenaran baik berupa materi maupun non materi. ${ }^{11}$

John Locke hanya memberikan atau mengungkapkan teori yang sebenarnya tentang HakAsasi Manusia, dan untuk pertama kalinya teori tersebut diungkapkan oleh kaum stoa yang dikemukakan olehZeno pada zaman Yunani Purba, yang kemudian pada zaman Romawi dibela oleh Cicero.

Hak Asasi Manusia menurut teori tersebut tidak perlu diakui oleh Negara, karena datangnya dari Tuhan Yang Maha Esa. Dengan meminta supaya Negara mengakui Hak Asasi Manusia maka akan merendahkannya dan menjadikannya legal rights serta membuat negara sebagai sumber daripadanya. Dengan demikian menurut teori ini, Hak Asasi Manusia dianggap sebagai hak-hak subyektif yang berkaitan dengan terjaminnya lingkungan kebebasan warga yang sebelumnya sudah ada walaupun belum diakui dan dilindungi oleh hukum positif.

Menurut Thomas Hobbes, manusia dipandang dalam keadaan alamiah (naturloestand), yang merupakan "serigala bagi sesamanya atau homo homini lupus dan saling memerangi antara sesamanya atau "bellum amnium centra amnes". Akan tetapi JohnLocke mamandang manusia dalam keadaan alamiahnyatidak sejelekpandangan Thomas Hobbes, karena manusia pada saat itu bermasyarakat walaupunmasih primitif.

Menurut S.W. Couwenberg, HakAsasi Manusia adalah penjabaran lebih lanjut daripada hak-hak yang paling fundamental, yaitu hak untuk menentukan nasibnya sendiri (self beschikringreehf), mungkin juga dapat dikatakan bahwa hak kebebasan untuk mengembangkan kepribadiannya sendiri (the right to the free development of this personality) adalah dasar daripada Hak Asasi Manusia walaupun tidak sefundamental. ${ }^{12}$

Dalam kaitan ini, Kuntjoro Purbopranoto memberikan pandangannya, hak kodrat yang paling asasi adalah hak hidup sebagai manusia. Tuhan Yang Maha Esa memerintahkan manusia di atas bumi ini untuk menunaikan fitrahnya terhadap yang menitahkan dan

\footnotetext{
${ }^{11}$ Ibid., hlm. 11

${ }^{12}$ Couwenberg, S.W, Moderne Constitusioneel Recht En Eman cipatieWomaen Liberale democratie als Eerste Emancipatie Model, Dalam Koesparmono Irsan, Algemene Leerstukken Gronderecht Naar Nederlands Recht, Tjenk Willink, 1998, hlm. 16
}

untuk itu baginya disediakan alat-alat perlengkapan yang diperlukan, baik badaniah maupun alamiah. Di atas dasar hak yang paling pokok dan universal itulah kemudian berkembang Hak Asasi Manusia (HAM). Dengan kata lain, hanya dengan paksaan dan bukan dengan perjanjian maka seseorang kehilangan kebebasannya. ${ }^{13}$

Pendapat lain tentangHakAsasi Manusia(HAM) juga dikemukakan oleh Georg Jellinek, ia memandang Hak Asasi Manusia sebagai hak reflek, artinya hak-hak tersebut diperoleh dari negara dan daya berlakunyapun sepenuhnya tergantung pada negara dan tata hukum positif. Sedangkan menurut Hans Kelsen, Hak Asasi Manusia merupakan bagian dari tata hukum yang berjenjang secara piramida dan yang secara terus-menerus berada dalam proses konkritisasi mulai dari grundnorm sebagai norma dasar tertinggi.

Di dalam ketentuan Undang-Undang Nomor 39 tahun 1999 tentang Hak Asasi Manusia dirumuskan "hak asasi manusia adalah seperangkat hak yang melekat pada hakekat keberadaan manusia sebagai makhluk Tuhan Yang Maha Esa dan merupakan anugerahnya yang wajib dihormati, dijunjung tinggi, dan dilindungi olehnegara, hukum, pemerintah, dan setiap orang demi kehormatan serta perlindungan harkat dan martabat manusia". ${ }^{14}$

Sedangkan menurut Piagam HakAsasi Manusia adalah hak dasar yang melekat pada diri manusia secara kodrati, universal, dan abadi sebagai anugerah Tuhan Yang Maha Esa. Meliputi hak untuk hidup, hak berkeluarga, hak mengembangkan diri, hak keadilan, hak kemerdekaan, hak berkomunikasi, hak keamanan, dan hak kesejahteraan.

Pada tahun 428 - 348 SM, Socrates dan Plato filosofYunani meletakkan dasar bagi perlindungan dan jaminan diakuinya hak-hak asasi manusia. Konsepsinya menganjurkan masyarakat untuk melakukan sosial kontrol kepada penguasa yang zalim dan tidak mengakui nilai kebenaran dan keadilan. ${ }^{15}$

Kemudian pada abad ke IV SM, Aristoteles menyatakan agar tercapai tujuan kehidupan manusia

\footnotetext{
${ }^{13}$ Koentjoro Purbopranoto, (ed), Hak Asasi Manusia Dalam Pancasila, Tjenk Willink : 1998, Hlm. 8

${ }^{14}$ Vide Pasal 1 angka 1 Undang-undang Nomor 39 Tahun 1999 tentang Hak Asasi Manusia

${ }^{15}$ Ramdlon Naning, Cita dan Citra Hak Asasi Manusia di Indonesia, (Jakarta: Lembaga kriminologi Universitas Indonesia Program Penunjang Bantuan Hukum Indonesia 1983), hlm. 8
} 
maka manusia membutuhkan manusia lain, oleh sebab itu mutlak diperlukan masyarakat agar individu dapat mempunyai arti sebagai manusia dan hanya dalam bermasyarakatlah manusia dapat berkembang sebagai individu. Atas pernyataan tersebutmanusia kemudian dinamakan dengan makhluk sosial.

Sejarah telah menoreh tonggak pertama lahirnya HAM terjadi di Inggris pada 15 Juni 1215 dengan lahirnya Piagam Magna Charta. Prinsip dasar dari piagam MagnaChartaitu antara lain memuat tentang kekuasaan Raja harus dibatasi dan hak asasi manusia lebih penting daripada kedaulatan Raja, tak seorang pun dari warga negara merdeka dapat ditahan atau dirampas harta kekayaannya atau diperkosa atau diasingkan kecuali berdasarkan pertimbangan hukum. ${ }^{16}$.

Adanya piagam Magna Charta yang merupakan pertanda munculnya perlindungan terhadap Hak Asasi Manusia (HAM) karena dalam piagam Magna Charta mengajarkan tentang hukum dan undangundang derajatnya lebihtinggi daripada kekuasaan Raja.

Pada tahun 1632-1704 John Locke berpendapat bahwa manusia yang berkedudukan sebagai warga negara hak-hak dasarnya dilindungi oleh negara, kemudian muncul teori kontrak sosial yang dikemukakan oleh J.J Rousseau yang berisi bahwa kekuasaan negara itu timbulnya karena dan berdasarkan atas suatu persetujuan kontrak antara seluruh masyarakat untuk membentuk suatu pemerintahan. ${ }^{17}$

Berdasarkan teori dari John Locke dan J.J Rosseau semakin kuat pula pergerakan untuk melindungi dan menjamin kebebasan hak dan kebebasan yang menjadi hakiki. Pada tahun 1689 keluarlah piagam Bill of Rights di Britania Raya yang merupakan undang-undang yang menyatakan hak dan kebebasan warga Negara dalam menentukan pergantian Raja.

Kemudian pada 4 juli 1776 pada saat revolusi Amerika keluarlah Declaration of Independence yang juga dianggap piagam HAM. Dalam Declaration of Independence yang ditandatangani oleh 13 (tiga belas) negara bagian Amerika ini berisikan pernyataan "bahwa sesungguhnya semua bangsa diciptakan sama derajat oleh Maha Pencipta, bahwa semua manusia dianugerahi oleh Pencipta hak hidup,

${ }^{16}$ Harun Pudjiarto, Hak Asasi Manusia Kajian Filosofis Dan Implementasinya Dalam Hukum Pidana Di Indonesia, (Yogyakarta: Andi Offset, 1999), hlm. 29

${ }^{17}$ Ibid., hlm. 10 kemerdekaan dan kebebasan untuk menikmati kebahagiaan". ${ }^{18}$

Piagam Declaration of Independence membuat Amerika sebagai negara yang mendapat kehormatan pertama dalam sejarah yang memberi perlindungan dan jaminan HAM dalam konstitusinya.

Pada tahun 1789 meletus revolusi Perancis, yang menghasilkan sebuah deklarasi yang amat terkenal, yaitu, "Declaration des droits de I'homme et du citoyen", atau Deklarasi tentang Hak-hak Manusia dan warga negara. Revolusi ini menuntut kebebasan warga negara Perancis dari kekangan cengkeraman kekuasaan diktator, Raja Louis XVI.

Dalam deklarasi ini dibedakan antara hak-hak yang dimiliki manusia sebagai manusia, yang dibawanya ke dalam masyarakat, dan hak-hak yang diperoleh manusia sebagai warga masyarakat dan warga negara. Hak-hak yang diperjuangkan sebagai hak manusia adalah hak atas kebebasan (liberty), hak milik, keamanan, dan perjuangan melawan penjajahan. Dasar pandangan ini adalah bahwa semua orang lahir bebas dan sama haknya. Sedangkan hak manusia sebagai warga negara, misalnya hak untukikut serta dalam pemilu, atau pembuatan undang-undang. Dokumen Perancis bertolak dari pandangan bahwa manusia adalah baik dan karena itu harus hidup bebas. Orang-orang lahir dan tinggal bebas dan sama bebasnya dihadapan hukum (les hommes naissent et demeurent librese et egaux en droit). ${ }^{19}$

Kemudian pada saat berkobarnya Perang Dunia II, D. Roosevelt presiden AS menandatangani Atlantic Charter pada 14 Agustus 1941 yang berisi tentang 4 (empat) kebebasan, yakni: ${ }^{20}$

1. Kebebasan untuk berbicara dan melahirkan pikiran (Freedom of speech and expression)

2. Kebebasan memilih agama sesuai dengan keyakinan dan kepercayaan (Freedom of religion)

3. Kebebasan dari rasa takut (Freedom offear)

4. Kebebasan dari kekurangan (Freedom of want)

Kebebasan-kebebasan yang dikemukakan oleh D. Rosevelt dimaksudkan untuk melawan penin-

${ }^{18}$ Ibid.

${ }^{19}$ Eduardus M. "Hak Asasi Manusia, Konsepsi dan Perwujudannya Menurut UUD 1945 Pasca Amandemen", makalah disampaikan dalam Lokakarya Penegakan HAM yang diselenggarakan oleh Kantor Kesbang dan Linmas Kab. Probolinggo 30 Nopember 2005 di Probolinggo, hlm. 2

${ }^{20}$ Ramdlon Naning, Op.Cit, hlm. 12 
dasan dan kekejaman melawan fasisme di bawah tekanan Hitler, dan juga merupakan tiảng penyangga hak-hak asasi manusia yang paling pokok dan mendasar. Pihak Sekutu juga menegaskan bahwa penyelesaian pasca perang harus mencakup komitmen untuk melindungi Hak Asasi Manusia.

Perkembangan Hak Asasi Manusia (HAM) menjadi bagian dari hukum internasional mencapai puncak perkembangannya dengan terbentuknya Perserikatan Bangsa Bangsa pada tahun 1946. Pada Piagam Perserikatan Bangsa-Bangsa (PBB) dan Statuta Mahkamah Internasional yang disahkan pada 26 Juni 1946. Aktifitas PBB untuk membantu perkembangan Hak Asasi Manusia (HAM) diperkuat pada Pasal 55 menyebutkan agar hak-hak asasi manusia dan kebebasan-kebebasan dasarnya ditaati. Meskipun Piagam PBB tampak lebih dulu mengakui perlindungan Hak Asasi Manusia(HAM),

Pada tahun 1946 juga disusunlah rancangan Piagam Hak-hak Asasi Manusia oleh organisasi untuk sosial ekonomi PBB yang terdiri dari 18 (delapan belas) anggota. Kemudian pada 1948 tepatnya 10 Desember sidang umum PBB menghasilkan Universal Declaration of Human Rights (Pernyataan sedunia tentang HAM) yang terdiri dari 30 Pasal. Majelis Umum PBB memproklamirkan pernyataan sedunia tentang Hak Asasi Manusia (HAM) sebagai "A common standart of achievement for all people and nations" suatu tolak ukur umum hasil usaha sebagai rakyat dan bangsa, dan majelis umum menyerukan semua anggota-anggota dan semua bangsa agar manjamin pengakuan hak-hak dan kebebasaankebebasan yang termaktub dalam pemyataan tersebut. ${ }^{21}$

Secara garis besar pernyataan tentang Hak Asasi Manusia (HAM) sedunia itu, di antaranya:

1. Pasal 1 dan 2, menyangkut hal-hal umum.

2. Pasal 3 sampai 21 memuat hak-hak sipil dan politik, di antaranya mencakup :22

a. Hak atas hidup.

b. Kebebasan dan keselamatan individu.

c. Bebas dari perbudakan

d. Bebas dari perlakuan tak berperikemanusiaan.

${ }^{21}$ Ibid.

${ }^{22}$ Scott Davidson, Hak Asasi Manusia, (Jakarta: Pustaka Utama Grafiti, 1994), hlm. 17 e. Hak pengakuan yang sama di depan undangundang.

3. Pasal 28 sampai 30, merupakan pasal penutup.

Kendati mengalami banyak kesulitan dalam mempromosikan dan melindungi HakAsasi Manusia (HAM), PBB juga menjalankan program untuk menyusun instrumen yang secara hukum mengikat guna menangani aspek-aspek Hak Asasi Manusia (HAM) secarakhusus. Instrumen-instrumen ituadalah traktat-traktat mengenai pencegahan dan penghukuman terhadap genosida, larangan terhadap diskriminasi seksual dan agama, pemusnahan dan penghukuman terhadap apartheid, larangan terhadap praktek penyiksaan, masalah pengungsi, dan konvensi khusus mengenai hak anak-anak. ${ }^{23}$

Pada tahun 1970 di Finlandia diadakan konferensi mengenai keamanan dan kerja sama yang lebih dikenal dengan perundingan Helsinki. Fungsi utama perundingan ini adalah membangun kerangka guna mengembangkan perdamaian dan keamanan Eropa, perundingan ini juga menghasilkan pemikiran formal mengenai isu Hak Asasi Manusia(HAM). Akhir * dari perundingan ini yang bersifat tidak mengikat adalah menyatakan untuk menghormati terhadap Hak Asasi Manusia (HAM) dan kebebasan yang fundamental, termasuk kebebasan berpikir, kebebasan berhati nurani, kebebasan beragama dan memeluk suatu kepercayaan tertentu serta menghormati hak-hak rakyat dan hak rakyat untuk menentukan nasib sendiri. Meskipun keputusan akhir dari perundingan tidak mengikat secara hukum, namun membantunegaradalam bidang HakAsasi Manusia(HAM), karena menegaskan norma-norma hak asasi yang telah diakui. Perundingan Helsinki dilanjutkan di Paris pada tahun 1990, yang menghasilkan pernyataan bahwa: ${ }^{24}$ Hak-hak asasi manusia dan kebebasan yang fundamental merupakan hak semua manusia yang diperoleh sejak lahir, tidak dapat dicabut dan dijamin oleh undang-undang. Proteksi dan promosi hak-hak ini merupakan tanggung jawab pertama pemerintah. Penghormatan terhadap hak ini merupakan jaminan yang esensial dalam menghadapi negara yang kuat.

Pada tahun 1993 diadakan konferensi Vienna Austria, yang menghasilkan beberapa rekomendasi

\footnotetext{
${ }^{23}$ Ibid, hlm. 19

${ }^{24}$ Ibid.
} 
mengenai Hak Asasi Manusia (HAM) yang lebih dikenal dengan Deklarasi Vienna. Rekomendasi tersebut di antaranya perlindungan hak-hak perempuan, anak, penduduk asli. Deklarasi Vienna juga memberikan rekomendasi konkrit untuk penguatan dan harmonisasi kemampuan sistem PBB dalam melakukan pemantauan kasus pelanggaran Hak Asasi Manusia (HAM).

Jika dahulu gerakan pemikir HAM dibangun karena adanya tindakan sewenang-wenang dari penguasa, maka saat ini HAM digerakkan dan dipikirkan dalam rangka menguatkan integrasi bangsa. Begitu urgensinya jaminan HAM ini bagi warga negara sehingganegaratidak dapatmain-main dengan kondisi yang serba dilematis ini karena gerakangerakan radikalisme memiliki jaringan yang kuat hampir di setiap negarakarena sifatnyayang terorganisir.

\section{KONSTITUSI SEBAGAI EMBRIO PENGEMBAN HAK ASASI MANUSIA (HAM) DI INDONESIA}

Sebagaimana penulis sebutkan di atas lahirnya Magna Charta pada tahun 1215 di Inggris melahirkan doktrin bahwa Raja harus tunduk pada aturan dan mulai bertanggung jawab kepada hukum. Sejak itu apabila Raja melanggar hukum harus diadili dan harus mempertanggungjawabkan kebijakannya kepada Parlemen. Jadi, sudah mulai dinyatakan bahwa Raja terikat kepada hukum dan bertanggung jawab kepada rakyat, walaupun kekuasaan membuat Undangundang pada masa itu lebih banyak berada di tangan Raja. Dengan demikian, kekuasaan Raja mulai dibatasi sebagai embrio lahirnya Monarkhi Konstitusional yang berintikan kekuasaan Raja sebagai simbol belaka. ${ }^{25}$ Raja tunduk kepada rule of the game yang dibuatnya.

Eksistensi dan stabilitas HakAsasi Manusia(HAM) tergantung dari sejumlah faktor penting antara lain: prinsip utama dari sistem nilai di luar hukum positif dan konstitusi, tingkat solidaritas kelompok, tingkat konsensus atas nilai-nilai tersebut, tingkat stabilitas politik, tipe sistem hukum dan pemerintahan, tahap perkembangan ekonomi tingkat kepercayaan terhadap produk hukum badan-badan legislatif dan peradilan, sifat dari komunikasi internal serta faktor pendidikan

${ }^{25}$ Harkristuti Harkrisnowo, "Perlu Kerja Sama untuk Implementasikan HAM", artikel dalam Dirjen HAM, 01 Mei 2007. yang dapat memprodusir suatu milieu nasional yang dapat mendukung dihargainya HakAsasi Manusia. ${ }^{26}$

Hak Asasi Manusia menurut Chomsky merupakan pengganti penentuan nasib sendiri (self $d e$ termination) sebagai nilai yang menjadi pedoman politik luar Negeri Amerika. ${ }^{27}$

Jika mencermati Indonesia sejarah bangsa Indonesia hingga kini mencatat berbagai penderitaan, kesengsaraan dan kesenjangan sosial, yang disebabkan oleh perilaku ketidakadilan dan diskriminatif atas dasar etnik, ras, warna kulit, budaya, bahasa, agama, golongan, jenis kelamin dan status sosial lainnya. Perilaku tidak adil dan diskriminatiftersebut merupakan pelanggaran hak asasi manusia, baik yang bersifat vertikal (dilakukan oleh aparat negara terhadap warga negara atau sebaliknya) maupun horisontal (antar warga negara sendiri) dan tidak sedikit yang masuk dalam kategori pelanggaran Hak Asasi Manusia (HAM) yang berat (gross violation of humanrights) dimanasebenarnyaHakAsasi Manusia (HAM) wajib dihormati dan dijunjung tinggi.

Kewajiban menghormati HakAsasi Manusia (HAM) tersebut, tercermin dalam Pasal 28J UUD NegaraRepublik Indonesia Tahun 1945, bahwa orang wajib menghormati hak asasi manusia orang lain dalam tertib kehidupan bermasyarakat, berbangsa, dan bernegara.

Dalam menjalankan hak dan kebebasannya, setiap orang wajib tunduk kepada pembatasan yang ditetapkan dengan undang-undang dengan maksud semata-mata untuk menjamin pengakuan serta penghormatan atas hak dan kebebasan orang lain dan untuk memenuhi tuntutan yang adil sesuai dengan pertimbangan moral, nilai-nilai agama, keamanan, dan ketertiban umum dalam suatu masyarakat demokratis.

Kebebasan dasar dan hak-hak dasar itulah yang disebut hak asasi manusiayang melekat pada manusia secara kodrati sebagai anugerah Tuhan Yang Maha Kuasa yang tidak dapat diingkari oleh siapapun. Pengingkaran terhadap hak tersebut berarti mengingkari martabat kemanusiaan.

Pancasila sebagai pandangan hidup bangsa, dasar Negara Kesatuan Republik Indonesia, ideologi

${ }^{26}$ Mulyana W. Kusumah, Hukum dan Hak Asasi Manusia : Suatu Pemahaman Kritis, (Bandung: Alumni, 1981), hlm. 35-36

${ }^{27}$ Ibid. hlm. 60 
bangsa Indonesia, dan sumber dari segala sumber hukum Negara di dalamnya terkandung nilai-nilai luhur bagi kehidupan bermasyarakat, berbangsa dan bernegara.

Nilai-nilai tersebut merupakan kristalisasi dalam pandangan hidup bangsa dan penjabarannya sesuai dengan butir-butir yang terkandung dalam silasilanya yang mengandung unsur-unsur tentang $\mathrm{Hak}$ Asasi Manusia (HAM) secara umum.

Di dalam pelaksanaan perlindungan Hak Asasi Manusia (HAM) ada kecenderungan masyarakat lebihmengutamakan hak-haknya daripada kewajibankewajiban asasi. Penuntutan hak-hak yang secara berlebihan atau tanpa batas yang jelas akan merugikan orang lain yang memiliki hak yang sama. Oleh karenaitu, dalam penegakan hukum HakAsasi Manusia (HAM) perlu peningkatan dari semua aparatur penegak hukum termasuk Komisi Nasional Hak Asasi Manusia.

Dalam kaitan ini menurut Dubes McCarthy, paling tidak ada 5 (lima) tantangan utama yang dihadapi Indonesia dalam rangka pemajuan dan perlindungan Hak Asasi Manusia (HAM): ${ }^{28}$

1. Dibutuhkan suatu bentuk pengelolaan atas usaha mencari keadilan bagi korban kekerasan di masa lalu dengan mekanisme untuk menghindari terjadinya kekerasan di masa yang akan datang.

2. Pengusutan pelanggaran HAM di masa lalu beserta pertanggungjawabannya selalu menjunjung asas keadilan dan berlangsung tanpa merusak usaha-usaha pemajuan dan perlindungan HAM di masa depan.

3. Dalam pembentukan sistem politik baru, adalah berbahaya jika perpedaan kelompok ditonjolkan ketimbang persamaannya.

4. Untukmemperhatikan keharmonisan sosial dalam masyarakat majemuk dalam proses rekonsiliasi.

5. Perlu ditemukan cara menyatakan pendapat secara damai dengan bebas dalam lingkungan yang penuh toleransi dan menghargai perbedaan pendapat.

Ada para ahli menyebutnya eksistensi Hak Asasi Manusia(HAM) di Indonesia sebenarnyajuga sudah diakui sejak lama. Sebagai contoh HAM di Sulawesi

${ }^{28}$ Sugeng Bahagijo dan Asmara Nababan, Hak Asasi Manusia: Tanggung Jawab Negara Peran Institusi Nasional dan Masyarakat, (Jakarta, 1999), hlm. 5-6.
Selatan pengenalan HAM telah ditulis dalam bukubuku adat kuno (Lontarak). Antara lain dinyatakan dalam buku Lontarak bahwa apabila raja berselisih faham dengan Dewan Adat, maka Raja harus mengalah, tetapi apabila para Dewam Adat sendiri berselisih, maka rakyatlah yang memutuskan.

Jadi prinsip Hak Asasi Manusia (HAM) yang telah disorot sekarang, semuanya sudah diterapkan oleh raja-raja dahulu, namun hal ini kurang diperhatikan karena sebagian ahli hukum Indonesia sendiri agaknya lebih suka mempelajari teori hukum Barat. Dengan demikian dapat disimpulkan bahwa HAM sudah lama lahir di Indonesia, namun dalam perkembangannya tidak menonjol karena kurang dipublikasikan.

Ada yang mengatakan bahwa pelaksanaan Hak Asasi Manusia (HAM) di Indonesia harus sesuai dengan latar belakang budaya Indonesia. Artinya, Universal Declaration of Human Rights kita akui, hanya saja dalam implementasinya mungkin tidak sama dengan di negara-negara lain khususnya negara Barat yang latar belakang sejarah dan budayanya berbeda dengan kita.

Negara-negara di dunia memiliki latar belakang perbedaan politik, sosial, ekonomi, budaya dan hukum serta pandangan para pendiri negaranya, yang tentunya berpengaruh dalam konsepsi perwujudan pengakuan dan jaminan perlindungan Hak Asasi Manusia (HAM) meskipun prinsip-prinsip universalitas mendasar Hak Asasi Manusia (HAM) tidak selalu identik dengan penyeragaman khususnya di Indonesia.

Perkembangan pesat konsepsi perwujudan pengakuan dan jaminan perlindungan Hak Asasi Manusia (HAM) dimulai sejak amandemen kedua UUD 1945 tanggal 18 Agustus tahun 2000 yang secara eksplisit memasukan ketentuan Hak Asasi Manusia (HAM) dalam bab dan Pasal-Pasal UUD RITahun 1945.

Sehubungan dengan maraknya masalah pelanggaran Hak Asasi Manusia, maka Pemerintah telah mengambil keputusan untuk membentuk Komisi Nasional Hak Asasi Manusia (KOMNAS-HAM) melalui Keputusan Presiden Republik Indonesia Nomor 50 Tahun 1993. Keputusan tersebut menyatakan bahwa Pemerintah mulai memberikan perhatian yang lebih serius pada persoalan Hak Asasi 
Manusia. Komitmen ini lebih lanjut diwujudkan dengan ditetapkannya Undang-Undang Nomor 39 Tahun 1999 tentang Hak Asasi Manusia yang menjadi acuan utama pemajuan dan perlindungan $\mathrm{Hak}$ Asasi Manusia di Indonesia serta dibentuknya Kantor Menteri Negara Urusan Hak Asasi Manusia dalam Kabinet Persatuan Nasional sesuai dengan Keputusan Presiden Republik Indonesia Nomor 355/M Tahun 1999.

Berdasarkan Keputusan Presiden Republik Indonesia Nomor 134 Tahun 1999, Kantor Menteri Negara Urusan HakAsasi Manusiamempunyai tugas pokok dan fungsi sebagai berikut : (1) perumusan kebijakan, (2) koordinasi, (3) peningkatan peran serta masyarakat dan (4) pelaporan dan evaluasi. Keputusan Presiden tersebut merupakan dasar arahan dalam upaya terhadap peningkatan Hak Asasi Manusia (HAM).

Dalam kajian dunia kontemporer Hak Asasi Manusia (HAM) ada beberapa generasi tentang konsepsi pemikiran perwujudan pengakuan dan jaminan perlindungan Hak Asasi Manusia(HAM), yakni:

Generasi Pertama, hak sipil dan politik. Prinsipnya adalah kebebasan manusia. (ex. peradilan yg adil dan tidak memihak, hak untuk tidak ditahan, hak untuk hidup, hak atas kebebasan atas keamanan dirinya, hak kebebasan berfikir, hak kebebasan berkumpul,hk berserikat, dll.)

Generasi Kedua, hak sosial dan ekonomi dan kebudayaan (prinsipnya adalah persamaan materiil). (ex, hak atas pekerjaan, hak untuk membentuk serikat pekerja, hak atas pensiun, hak atas kehidupan yang layak bagi dirinya.

Generasi ketiga, Prinsipnya solidaritas bangsabangsa: hak menentukan nasib sendiri, hak perdamaian, dll.

Generasi keempat, yang mengkritik peranan negara yang sangat dominan dalam proses pembangunan yang terfokus pada pembangunan ekonomi dan menimbulkan dampak negatifseperti diabaikannya aspek kesejahteraan rakyat. Selain itu program pembangunan yang dijalankan tidak berdasarkan kebutuhan rakyat secara keseluruhan melainkan memenuhi kebutuhan sekelompok elit.

Pemikiran Hak Asasi Manusia (HAM) generasi keempat dipelopori oleh Negara-negara di kawasan Asia yang pada tahun 1983 melahirkan deklarasi hak asasi manusia yang disebut Declaration of the basic Duties of Asia People and Government.

Dalam konteks Indonesia Eduardus mengemukakan, bahwa ketentuan tentang Hak Asasi Manusia (HAM) dalam UUD 1945 hasil amandemen dapat dikelompokkan ke dalam 3 (tiga) kategori, yaitu : HAM generasi pertama, mengcakup hak sipil dan politik (civil and political rights) seperti yang ditetapkan dalan Pasal 28 UUD 1945. HAM generasi kedua, mencakup hak sosial, ekonomi dan budaya, seperti yang tercantum dalam Pasal 27 ayat (2), Pasal 28C ayat (1). HAM generasi ketiga, mencakup hak menentukan nasib sendiri, hak persamaan bagi setiap orang. ${ }^{29}$

Sebagai perwujudan anutan paham HAM pada tataran peraturan pelaksanaan UUD 1945, telah hadir Undang-Undang Nomor 39 Tahun 1999 tentang Hak Asasi Manusia dan Undang-Undang Nomor 26 Tahun 2000 tentang Pengadilan HAM. ${ }^{30}$

Mengingat kondisi gerakan radikalisme yang mengkhawatirkan integrasi bangsa saat ini, maka diperlukan proses internalisasi pengakuan dan jaminan HAM yang tidak hanya secara normatif konstitusioal, melaikan secara empirik bagi setiap orang yang hidup bersama dengan orang lain di negara Indonesia ini, maka pendekatan pengayoman dari negara sangat diperlukan agar warganya tidak brutal sehingga mudah bergabung dengan gerakan-gerakan yang tidak cocok dengan paham Indonesia negara hukum Pancasila.

Prinsip perlindungan hukum terhadap HAM bertumpu dan bersumber dari konsep tentang pengakuan dan perlindungan terhadap HAM, karena pengakuan dan perlindungan terhadap HAM diarahkan kepada pembatasan-pembatasan tindakan kesewenang-wenangan dari penguasa meletakkan kewajiban kepada pemerintah untuk mengakui dan menjaminnya sekaligus menghormatinya bagi pemerintah dan masyarakat.

Saat ini seiring dengan berkembangnya gerakan radikalisme transnasional yang mengkhawatirkan berimbas kepada disintegrasi bangsa, maka prinsip pengakuan dan jaminan perlindungan HAM diarahkan dalam rangka mengayomi, melindungi, memberikan rasan aman, rasa tentram dan khusus-

\footnotetext{
${ }^{29}$ Eduardus M. Bo, Op.Cit., hlm. 7
}

${ }^{30}$ Ibid. 
nya memberikan jaminan kesejahteraan dari negara karena bergabungnya segelintir warga negara kepada gerakan radikalisme sepertinya mereka merasa terpanggil karena kondisi ekonomi bukan sematamata karena jihad dalam makna paham mereka.

Dalam konteks strategi penguatan integrasi bangsa melalui implementasi pengakuan jaminan perlindungan HAM dari negara implementasinya menunjukkan adanya hubungan kekuasaan antara negara mengatur rakyatnya dan rakyat untuk mendapat pengakuan dan jaminan perlindungan pemenuhan HAM.

\section{KESIMPULAN}

Eksistensi gerakan radikalisme akhir-akhir ini mencemaskan kondisi kehidupan berbangsa dan bernegara dalam tertib kehidupan dunia, karena gerakan itu mampu menarik simpati orang lain dari berbagai kalangan dan berbagai warga negara di dunia yang menyakini akan paham dan ajaran yang ia tawarkan. Gerakan ini cepat atau lambat akan mempengaruhi stabilitas nasional maupun interna"sional karena sifatnya terorgansir, sehingga dalam kajian penulis, adanya penguatan pengakuan dan jeminan HAM khususnya kesejahteraan dari negara agar warga negara Indonesia tidak mudah tergiur tawaran yang ditawarkan oleh kelompok gerakan radikalisme ini. Jika dahulu gerakan pemikir HAM dibangun karena adanya tindakan sewenangwenang dari penguasa, maka saat ini HAM digerakkan dan dipikirkan dalam rangka menguatkan integrasi bangsa. Jika negara serius memberikan pengakuan dan jaminan secara normatif dan empirik terhadap warganya tat kala pengakuan dan jaminan HAM itu diberikan, warga terasa dilindungi, terasa diayomi yang pada gilirannya akan timbul rasa simpati dan empati terhadap pemerintah dan negaranya, sehingga integrasi bangsaakan tetap utuh dan terjalin.

\section{BAHAN BACAAN}

Bahagijo, Sugeng \& Asmara Nababan, 1999. Hak Asasi Manusia: Tanggung Jawab Negara Peran Institusi Nasional dan Masyarakat, Jakarta.

Budiardjo, Miriam 1988. Dasar-Dasar Ilmu Politik. Jakarta. Gramedia.
Davidson, Scott. 1994. Hak Asasi Manusia: Sejarah, Teori dan Praktek Dalam Pergaulan Internasional. Jakarta. Pustaka Utama Grafiti.

Eduardus Marius Bo, 2005, "Hak Asasi Manusia, Konsepsi dan Perwujudannya Menurut UUD 1945 Pasca Amandemen", makalah disampaikan dalam Lokakarya Penegakan HAM yang diselenggarakan oleh Kantor Kesbang dan Linmas Kab. Probolinggo, 30 Nopember 2005 di Probolinggo.

Hamid, Shalahuddin. 2003. Hak Asasi Manusia Dalam Perspektif Islam, cet. Ke-2. Jakarta. Amissco.

Harkrisnowo, Harkristuti, "Perlu Kerja Sama untuk Implementasikan HAM", artikel dalam Dirjen HAM, 01 Mei 2007. : www.depkhumham. go.idhtml.

M. Luqman Hakiem. 1993. Dekalarasi Islam Tentang HAM, Surabaya. Risalah.

Mahfud MD, Moh. 1993. Demokrasi dan Konstitusi di Indonesia. Yogyakarta.

Maududi, Mawlana Abu A'la. 2000. Hak-Hak Asasi Manusia Dalam Islam . Terjemahan dari Human Right in Islam oleh Bambang Iriana Djajaatmadja. Jakarta. Bumi Aksara.

Mawlana Abu A'la Mawdudi, 2000. Hak-Hak Asasi Manusia Dalam Islam . Terjemahan dari Human Right in Islam oleh Bambang Iriana Djajaatmadja, Jakarta.

Naning, Ramdlon. 1983. Cita dan Citra Hak Asasi Manusia di Indonesia. Jakarta. Lembaga kriminologi Universitas Indonesia Program Penunjang Bantuan Hukum Indonesia.

Pudjiarto, Harun. 1999. Hak Asasi Manusia Kajian Filosofis Dan Implementasinya Dalam Hukum Pidana Di Indonesia. Yogyakarta. Andi Offset.

Purbopranoto, Koentjoro (ed). 1998. Hak Asasi Manusia dalam Pancasila, Tjenk Willink.

W. Kusumah, Mulyana. 1981. Hukum dan Hak Asasi Manusia: Suatu Pemahaman Kritis. Bandung. Alumni.

Wahid, Abdul dan Muhammad Irfan. 2001. Perlindungan Terhadap Korban Kekerasan Seksual: Advokasi Atas Hak Asasi Perempuan. Bandung. Refika Aditama. 
